\title{
Female Characters in Ismat Chugtai's Short Stories
}

\section{Brahmjot Kaur}

Research Scholar, Department of English and MEL, University of Lucknow, India

\begin{abstract}
Chugtai is a leading name amongst female Urdu writers of this century. Chugtai's contribution is easily sequestered to her bold narrative in her famous short story "Quilt", but the author wrote many other short stories with substantial gravitas. This paper thereby is an attempt to assess female characters in her lesser known stories, and highlight the author's deftness at bringing up female issues which others felt scared to discuss about. Chugtai is vociferous, her voice is not one to be easily snubbed and she is relevant. She was way ahead of her times, and thereby her stories strike a chord even today.
\end{abstract}

Keywords-belong, desire, sexuality.

\section{FEMALE CHARACTERS IN ISMAT CHUGTAI'S SHORT STORIES}

No sooner does one think of Chugtai than one is reminded of "Lihaf" and a mental image of a shadow of an elephant on a wall, is invoked. For me Chugtai's name was synonymous with 'Lihaf' for years. Later, Kubra from Chugtai's“' Chauthi Ka Joda”, and her journey deeply moved me. Lately this led me to reading more of her short stories which consequently led me to this paper. This paper thereby is my reading of lesser known stories of Chugtai and the female characters portrayed therein. Chugtai's insight into female sexuality, female psychology and female issues is heterogeneous. She does not talk of or show dedication to a single issue, does not restrict her female characters to any particular strata of society or religion. Her characters are diverse and so are their varied life-conditions. Chugtai's feminism is layered, and each character from each story adds to it. Moreover, Chugtai's stories are neither didactic, nor propagandist. Her female characters respond in their own individual ways to their conditions but do not justify or preach anything as being the correct thing to do. That is left for the reader to discern.Chugtai wrote about female sexuality and issues in times when it was completely tabooed by society. In the words of Patel "Ismat Chughtai was nothing if not bold. Writer after writer, friends, relatives, companions, attested to her remarkable obstinate demand to disturb the civil, to disrupt the ideas that constituted civility, to upend the notions that gave force to how women ought to be. As a supplicant asking for our attention, she was ironic, playful, moving, funny, cutting, witty, she spoke to desire and grief, but rarely succumbed to propriety" (Patel 2)

Gainda, the eponymous first story in the anthology showcases a widower lower caste girl who is seduced by the narrator's 'bhaiya' but not given the rights of a wife. In a bewildering moment the narrator once sees her friend, housemaid Gainda slapping her brother in private. Her brother, feared by everyone in family gave Gainda, his beloved the right to slap him during their banter, but succumbed to the societal norms in giving Gainda her due openly. Gainda's pregnancy, her malnourished child suckling at her breast, and her yearning for her son's father, are all heart wrenching. While the patriarchal society attaches immense importance to the child bearing duty of a female, Gainda and her son are non-acceptable for she is a widower, unacceptable low caste, and Lallu is a child out of wedlock. The same anthology has a story titled "Touch-me-not", where the legally wedded wife of the narrator's brother, bhabhijan is unable to bear a child. A complete foil to Gainda, the fragile Bhabhijan is an under-age bride who conceives but miscarries everytime. She is aware that her inability societally legitimizes the entry of another wife in her husband's life, though he already frequents nautch-girls. Such is the fate of these women, Gainda is just like the flower Gainda, which is used to adorn houses, prayer-rooms and even idols of Gods and Goddesses, but thrown away soon after the purpose is fulfilled, while Bhabijaan who is 
diligently cared for, given rights, but once all hopes of bearing a child are shattered, she knows she would lose it all, "In the absence of a provider, she could resort to one thing only- that is, to render the same service to everybody which was, so far, exclusive to her husband (66).

Lajo, from the story "homemaker" is a captivating character. Her situation in life has made her endorse very broad notions of sexuality and marriage, but the inner desire to truly belong is as strong as any other human being's. The title of the story is interesting but apt. While such women are believed by society to be home-breakers, Lajo actually makes Mirza's home worth living. She gladly performs all household chores.Lajo openly flaunts her body, but once in Mirza's house she refrains from any illicit liaison. The insecure male is haunted by the fear of losing her to other men, and compels her to enter into marriage with him. Once tied, Mirza loses his interest in Lajo, and frequents prostitutes, while Lajo's freedom is throttled by marriage, Mirza's norms, his wish for her to wear 'Salwar-Kameez' and his indifference. Lajo's infidelity stems from Mirza's perpetual negligence. Strangely, what is infidelity in Lajo's case is permissible to Mirza.Lajo is beaten mercilesslybut she takes it without any opposition. Moreover, Mirza is not shattered by her relationship with a nearby boy, but by the insult that has been caused by it. The moment his friend suggests that the marriage to Lajo is invalid in the eyes of Muslim law, since Lajo was an illegitimate child without any knowledge of whereabouts, Mirza's trouble is solved, and so is Lajo's. The homemaker returns and Mirza's interest in her revives. Chugtai seems to be asserting that marriage is not always the only right thing to do for happy existence. Various other questions are raised through this story. The idea of fidelity is challenged, the idea of marriage is questioned and also the idea of Laaj, i.e. dignity is mocked upon. Very similar is the attitude of Rani, the protagonist in the story titled "Mole". Much like Lajo, she is from the lower section of the society, has no rigid scruples about physical intimacy, since that is what sustains her life, but at the same time has the desire to belong. Both these women have accepted and embraced their sexuality and sexual desires, unlike many who are still ashamed of talking about it. Rani is a complete contrast to Choudhary. Choudhary is from elite society, and is chained by laws of patriarchal world. He does not accept his desire for Rani, but is jealous of all her other relationships. He calls her indecent for vocalizing her sexual needs, or talking of her mole, but does not realize his indecency in stirring her feelings but not openly responding to them. In the end when she labels Choudhary as impotent he is unable to take that too. The painter has the audacity and desire to paint the downtrodden woman naked, but lacks the audacity to accept her overtures. Rani on her part is uninhibited, unapologetic and truthful to her sexuality and nothing restrains her from accepting what she felt and needed.

"All Alone" is a story ahead of its times. A mature love story of Shahzad Hasan and Dilshad Mirza. One is most intrigued by the character of Sylvia, Dilshad's wife. Probably it is easier to imagine someone like Sylvia today, but back then, and to write of it, is appalling. The young lovers never confess, and are separated by social status and their respective families' objection to the match. They are further separated by Partition, and almost thirty years later, Sylvia makes the two confront and confess. Giving their entire life for love, all three of them gladly embrace their realities. Sylvia's fiance's death, her marriage to Dilshad, his love for Shahzad is understandable, but the meeting arranged by Sylvia, her encouragement to open up, and their cordial relationship is quite appreciable. Unlike any fantastical movie which would have ended in the wedding of the couple, Chugtai chooses to leave that unsettled. Just the fact "that the feeling was not one-sided, that you were also touched by it " (106) has been resolved. The married couple leaves and Shahzad happily returns to her paintings, for in art is an artist's true existence. Chugtai's treatment is mature, sensitive and not fairy-tale like. The friendship that the three begin to share with all unsaid finally expressed is beautiful and unique in everyway.

"I'll break your hands if you raise them to hit her again" (123) these words are said by a mother-in-law, to her own son, in favor of her daughter-in-law. The situation is mostly the complete opposite. Even today, mothers-in-law have major role in domestic violence. Chugtai's portrayal of the mother in law is realistic, who keeps chiding her daughter-in-law all through the day, keeps her busy in one or the other work to prevent her from playing with street kids, but does not let her son abuse her or scold her, even in a happy banter. She cares for her when she gets bruised, bringing out the motherly side. The 'bahu' equally reciprocates the feeling of affection and does not mind any of her initial scolding, for she knows of the inner parental side. Such joyous and realistic portrayal is a treat to read.

"Quit India" is more about the Anglo-Indian British official who is unable to leave India post the Indian Independence, but still the two minor female characters hold 
importance. His English wife represents the Eurocentric colonizer, with all their prejudices for the native. She despises the native and the climate, considers Jackson's disinterest responsible for their failing marriage, and tries hard to elevate Jackson's position through her father's sources, but is ultimately left to go back to England alone. Sakkubai is a foil to her memsahib. She does not mind giving her position to memsahib for the days that she comes to India. She cares for Jackson like a child, for it is Jackson with whom she belongs, her "man" (85). Life with Jackson saves her from her prostitute-like existence with Ganpat. Even later, when Jackson loses his position, she stays by his side till the very end. She is the embodiment of female notion of commitment; though not a wife she still understands his psychology and gives him the needed refuge beyond linguistic and cultural barriers.

\section{CONCLUSION}

To conclude Chugtai's female characters are relevant. They display Indian sensibility aptly and put forward the issues of Indian feminism through their lives. Even in these lesser read works of Chugtai, her women characters are relatable. There is an aspect of realism strongly evident in all these female characters, as in her own words, "the artist's duty to describe the world as he or she finds it; the unfeasibility of passing absolute judgment on literary texts; the denial of corrupting influence of literature..." (Naqvi 76). Her female characters potently bring out the wrongs that society keeps doing to women. Almost all of Chugtai's female characters are more progressive than their counterparts. They have embraced their sexuality and do not in any way feel ashamed of it. Chugtai must have faced backlash from patriarchal sections during her lifetime, but she created a niche for herself, and left behind a body of work which still resonates with females and gender studies. She is rightly referred to as an "iconoclastic", "enlightened", "bold", "progressive" and "feminist" writer (Parekh, 2015). This paper is therefore an attempt to give the writer and these less popular works their due, so that even these works can be seen as manifestations of her delicate understanding of female sexuality.

\section{REFERENCES}

[1] Chugtai, Ismat. Translated by $\mathrm{M}$. Asaduddin. The Quilt:Stories. Penguin Evergreens, 2011.
[2] Chughtai,Ismat. Translated by TahiraNaqvi. We People. My Friend, My Enemy: Essays, Reminiscences, Portraits. Kali for Women, 2001.

[3] Parekh, Rauf. "IsmatChughtai:Her life, thought and art", Dawn, 30 ${ }^{\text {th }}$ August 2015.

[4] Patel, Geeta. An Uncivil Woman: IsmatChughtai. Annual of Urdu Studies, vol. 16 . 2001. 